\title{
Emissions Trading and the Potential Benefits for ASEAN: Exploring the Possibilities for Brunei Darussalam
}

\author{
Andi Tabrani ${ }^{1}$, Roger Neil Lawrey ${ }^{2} \&$ Janaki Ram Pillarisetti $^{1}$ \\ ${ }^{1}$ Faculty of Business, Economics and Policy Studies, University of Brunei Darussalam, BE, Brunei Darussalam \\ ${ }^{2}$ School of Accounting, Economics and Finance, University of Southern Queensland, Toowoomba, Qld., \\ Australia \\ Correspondence: Roger Lawrey, School of Accounting, Economics and Finance, University of Southern \\ Queensland, Toowoomba, Qld 4350, Australia. Tel: 673-881-0745. E-mail: rogerlawrey@gmail.com
}

Received: October 1, 2012 Accepted: October 22, 2012 Online Published: October 26, 2012

doi:10.5539/jsd.v5n11p46 URL: http://dx.doi.org/10.5539/jsd.v5n11p46

\begin{abstract}
This paper reviews international agreements related to carbon trading, and examines ASEAN countries' participation in the Clean Development Mechanism (CDM). It presents information on the forest and energy sectors in Brunei and explores the potential for Brunei's participation in carbon trading. It concludes that there is considerable potential for greater involvement of ASEAN in general and of Brunei Darussalam in particular and that the revenues from trading could offset higher capital costs of investments in efficiency and renewable energy technologies.
\end{abstract}

Keywords: energy, forests, carbon trading, ASEAN, Brunei Darussalam

\section{Introduction}

This paper explores the potential benefits to small nations such as Brunei Darussalam from being engaged in the newly developing market for carbon trading and offsets. With the emergence of targets for the reduction of greenhouse gases as a means of addressing climate change, markets have emerged for the trading of carbon permits. The Kyoto Protocol introduced the Clean Development Mechanism (CDM) scheme under which developing countries can participate in emission trading. The fundamental concepts involved in emissions trading are to produce least-cost solutions, in aggregate, to achieve a certain level of emission reduction. Countries or firms with high pollution abatement costs can purchase permits to pollute from countries or firms with low pollution abatement costs.

The CDM mechanism is designed to reduce carbon output by changing behaviour and systems, so countries/firms can potentially gain by, for example, increasing energy efficiency or reducing de-forestation. Brunei produces greenhouse gases through the production of crude oil and natural gas and through its use of petrol and natural gas-generated electricity. But it is also a major absorber of carbon through the large area of forested land in the country. Brunei has a commitment to maintain at least 55 per cent of the country as permanent forest reserve, and conducts very limited commercial logging. Brunei has been very environmentally conscious in the preservation of its forests but indulges in excessive use of electricity resulting from highly subsidized energy prices (oil, gas and electricity).

This paper investigates how ASEAN countries like Brunei can benefit from carbon trading. The paper is organized as follows: Section 2 discusses the theoretical background to carbon trading, Section 3 explains the current state of international agreements related to climate change and carbon trading, Section 4 discusses the carbon market, the Clean Development Mechanism and how ASEAN countries have participated in the market. Section 5 presents information on the forest and energy sectors in Brunei and explores the potential for its participation in CDM and carbon trading. Conclusions are presented in Section 6.

\section{Theoretical Background}

Emission trading refers to the transfer of pollution rights to achieve a target reduction in pollution in order to deal with environmental problems (Common \& Stagl, 2005). The principle of emission trading is that any increase in emissions from one source must be offset by a decrease in emissions of the same amount elsewhere. The theoretical underpinnings of emissions trading originated in the Pigovian framework that internalised externalities 
by imposing a tax equal to marginal external cost at optimal output (such as a carbon tax). Coase developed a more market oriented approach based on property rights, which in this case are emission trading permits. These two approaches have generated much policy debate (Helm, 2005). Emission trading is, at least in theory, a least cost solution to achieving a given level of pollution reduction. All participants will have an incentive to buy permits if the price is below their marginal cost of abatement and sell permits if the price is above their marginal abatement cost. The result is that the participants with high costs of abatement buy permits and abate less while those with low costs of abatement sell permits and abate more. This situation will lead to the situation where all participants have the same marginal abatement cost and total abatement costs are minimized. In addition, emissions trading schemes promote innovation and investment in new abatement technologies as firms attempt to reduce their marginal abatement costs and therefore the price they have to pay for permits.

\section{International Agreements and Institutional Arrangements}

Brunei ratified the Kyoto Protocol in 2009 and has become one of the Non-Annex I Parties, which allows it to take part in emissions trading through CDM projects. Non-Annex 1 countries can also participate in climate change mitigation through the Reducing Emissions from Deforestation and Degradation (REDD+) framework (Haites, 2008). These countries have no obligation to reduce their greenhouse gas emissions under the protocol. To date there are 2,382 projects registered and approved by the CDM Executive Board of the United Nations Framework Convention on Climate Change (UNFCCC). More than 75 per cent of these projects are located in the Asia-Pacific region and are dominated by China. ASEAN has 245 projects in eight countries that are participating in the scheme. Only Brunei and Myanmar do not participate in CDM projects. The CDM projects cover Energy Efficiency (EE) and Renewable Energy (RE) under the category of emissions reduction, while afforestation and reforestation (A/R) are grouped as a separate category. The Copenhagen Accord of 2009 recognized that in order to meet the ultimate objective of the UNFCCC, the global temperature should increase by less than two degrees Celsius. Annex I Parties have committed to set emission targets for 2020, which could be implemented individually or jointly. Moreover, Non-Annex I Parties should implement mitigation actions and report the actions and emission inventories every two years.

The CDM mechanism will assist Non-Annex I Parties in achieving sustainable development and contributing to the stabilization of greenhouse gas concentrations in the atmosphere (United Nations Framework Convention on Climate Change (UNFCCC), 2008). The other purpose of this mechanism is to assist the Annex I Parties (developed countries) in achieving their emissions targets. The rules establish an international process for reviewing the emission reduction achieved by each CDM. Under the Kyoto Protocol emissions trading scheme, the Annex I Parties can trade their AAUs, ERUs, CERs and RMUs, in tons of $\mathrm{CO}_{2} \mathrm{e}$ (carbon dioxide equivalent) (Note 1).

\section{The Carbon Market, CDM and ASEAN Countries}

In 2008, the carbon market was worth US\$126.3 billion with approximately 72 per cent of trade within the European Union Emission Trading Scheme (EU ETS) (Capoor \& Ambrosi, 2009); the market doubling from 2007 size of US\$. In addition, the secondary market for CERs in 2008 was more than US\$26 billion, an increase of almost five times from 2007. Project-based transactions in 2008 decreased by 12 per cent compared to 2007 . These transactions include primary CDM, Joint Implementation and the voluntary market. In 2008, about $123.4 \mathrm{Mt} \mathrm{CO}_{2} \mathrm{e}$ have been traded in the voluntary markets (Benwell, 2009).

The CERs created by CDM projects in developing countries have been sold into emissions markets, such as the EU ETS. In this case, both CERs and ERUs are allowed to be included in the market. Many governments have bought those units as offsets against their Kyoto Protocol targets (Murphy, Drexhage \& Wooders, 2009). China and India are hosts for 64 per cent of total CDM projects around the world. Meanwhile, other countries that are active in CDM projects are Brazil, Mexico and Malaysia. The largest buyers of CERs are the United Kingdom, Switzerland, Japan and the Netherlands.

The ASEAN region has the potential to be host to many CDM projects in several areas such as biogas, biomass and landfill gas projects. Biomass is abundant in this region and also commonly used in rural areas and the industrial sector. Besides those projects, rich natural endowments in this region such as solar, wind and hydro can also support CDM projects. Energy efficiency is another potential area for developing CDM projects in this region as all ASEAN countries promote energy efficiency at the national level. The $\mathrm{CO}_{2}$ emissions rate in ASEAN countries increased during the period $1980-2008$, with the highest emissions generated by the consumption of petroleum products. The emission from coal consumption increased at an accelerating rate after 2003, caused by the increase in demand for electricity by industry and the residential and commercial sectors. The second highest rate of $\mathrm{CO}_{2}$ emission is generated by the consumption of coal, followed by natural gas consumption. For some ASEAN 
countries, developing CDM projects will create benefits, particularly related to clean technology implementation. The implementation of these projects would contribute to the reduction of $\mathrm{CO}_{2}$ emissions and environmental degradation in the long term. There are $245 \mathrm{CDM}$ projects hosted by ASEAN countries which fall into several types of CDM activities as shown in Table 1.

Table 1. Number of registered CDM projects in ASEAN by country 2010

\begin{tabular}{|c|c|c|c|c|c|c|c|c|c|}
\hline $\begin{array}{c}\text { Project } \\
\text { Category }\end{array}$ & Cambodia & Indonesia & $\begin{array}{l}\text { Lao } \\
\text { PDR }\end{array}$ & Malaysia & Philippines & Singapore & Thailand & Vietnam & ASEAN \\
\hline Biomass energy & 1 & 8 & - & 21 & 3 & 1 & 7 & 1 & 42 \\
\hline Cement & - & 1 & - & - & - & - & - & - & 1 \\
\hline EE industry & - & 1 & 1 & 3 & - & - & - & - & 5 \\
\hline $\begin{array}{l}\text { EE own } \\
\text { generation }\end{array}$ & 1 & - & - & - & 1 & - & 3 & - & 5 \\
\hline EE supply side & - & 2 & - & 1 & - & - & - & & 3 \\
\hline $\begin{array}{c}\text { Fossil fuel } \\
\text { switch }\end{array}$ & - & 1 & - & - & - & - & - & - & 1 \\
\hline $\begin{array}{l}\text { Fugitive } \\
\text { emission }\end{array}$ & - & 1 & - & - & - & - & - & 1 & 2 \\
\hline Geothermal & - & 2 & - & - & 1 & - & - & - & 3 \\
\hline Hydro & - & - & - & 1 & 1 & - & - & 17 & 19 \\
\hline Landfill gas & & 6 & - & 5 & 3 & - & 2 & 2 & 18 \\
\hline $\begin{array}{l}\text { Methane } \\
\text { avoidance }\end{array}$ & 2 & 23 & - & 52 & 30 & - & 24 & 7 & 138 \\
\hline $\mathrm{N}_{2} \mathrm{O}$ & - & 1 & - & - & 1 & - & 1 & - & 3 \\
\hline PFCs and SF6 & - & 1 & - & - & - & - & - & - & 1 \\
\hline Reforestation & - & & - & - & - & - & - & 1 & 1 \\
\hline Solar & - & 1 & - & - & - & - & - & & 1 \\
\hline Wind & - & - & - & - & 1 & - & - & 1 & 2 \\
\hline Total & 4 & 48 & 1 & 83 & 41 & 1 & 37 & 30 & 245 \\
\hline
\end{tabular}

Data Source: UNEP Risø CDM/JI pipeline analysis and database, 2010.

From Table 1, Malaysia has the largest number of CDM projects followed by Indonesia and the Philippines. Brunei and Myanmar are the only two ASEAN countries without any CDM projects. Table 2 shows the estimated CERs for 2012 generated by the projects specified in Table 1. Malaysia is expected to generate the highest amount of CERs in 2012 compared to other ASEAN countries. A significant amount of CERs are expected to be generated by biomass energy projects related to palm oil solid waste from the vast oil palm plantations throughout the country.

In Indonesia, almost 30 per cent of CERs come from methane avoidance projects. Most of these projects are related to waste water. Other projects are biomass energy and, similarly with Malaysia, many of these projects are related to palm oil solid waste from oil palm plantations in Sumatera and Kalimantan. Geothermal projects are estimated to account for approximately 16 per cent of total CERs and Indonesia has many geothermal resources throughout the country. The potential of geothermal is estimated at approximately 9,076 megawatts, located in 50 fields that could be developed as CDM projects in the future. To date, only two countries in ASEAN have geothermal projects as registered CDM projects, namely Indonesia and the Philippines. Only Indonesia has CDM projects related to solar power. 
Table 2. Estimated 2012 CERs in ASEAN (Kilotons $\left.\mathrm{CO}_{2} \mathrm{e}\right)$

\begin{tabular}{|c|c|c|c|c|c|c|c|c|c|}
\hline $\begin{array}{l}\text { Project } \\
\text { Category }\end{array}$ & Cambodia & Indonesia & $\begin{array}{l}\text { Lao } \\
\text { PDR }\end{array}$ & Malaysia & Philippines & Singapore & Thailand & Vietnam & ASEAN \\
\hline $\begin{array}{c}\text { Biomass } \\
\text { energy }\end{array}$ & 413 & 3492 & - & 11148 & 519 & 30 & 2092 & 112 & 17806 \\
\hline Cement & - & 1879 & - & - & - & - & - & - & 1879 \\
\hline EE industry & - & 85 & 13 & 851 & - & - & - & - & 949 \\
\hline $\begin{array}{l}\text { EE own } \\
\text { generation }\end{array}$ & 81 & - & - & - & 190 & - & 640 & - & 911 \\
\hline $\begin{array}{l}\text { EE supply } \\
\text { side }\end{array}$ & - & 167 & - & 2184 & - & - & - & - & 2351 \\
\hline $\begin{array}{l}\text { Fossil fuel } \\
\text { switch }\end{array}$ & - & 79 & - & - & - & - & - & - & 79 \\
\hline Fugitive & - & 1173 & - & - & - & - & - & 2126 & 3299 \\
\hline Geothermal & - & 2609 & - & - & 269 & - & - & - & 2878 \\
\hline Hydro & - & & - & 238 & 190 & - & - & 1495 & 1923 \\
\hline Landfill gas & - & 1390 & - & 2012 & 2162 & - & 485 & 799 & 6848 \\
\hline $\begin{array}{c}\text { Methane } \\
\text { avoidance }\end{array}$ & 239 & 4677 & - & 6651 & 745 & - & 5396 & 920 & 18628 \\
\hline $\mathrm{N}_{2} \mathrm{O}$ & - & 323 & - & - & 82 & - & 1163 & - & 1568 \\
\hline $\begin{array}{l}\text { PFCs and } \\
\text { SF6 }\end{array}$ & - & 390 & - & - & - & - & - & - & 390 \\
\hline Reforestation & - & - & - & - & - & - & - & 7 & 7 \\
\hline Solar & - & 18 & - & - & - & - & - & - & 18 \\
\hline Wind & - & - & - & - & 142 & - & - & 165 & 307 \\
\hline Total & 733 & 16282 & 13 & 23084 & 4299 & 30 & 9776 & 5624 & 59841 \\
\hline
\end{tabular}

Data Source: UNEP Risø CDM/JI pipeline analysis and database, 2010.

Thailand is estimated to generate approximately 9,776 kilotons of $\mathrm{CO}_{2} \mathrm{e}$ by 2012 from $37 \mathrm{CDM}$ projects. Most of Thailand's CERs are generated by methane reduction projects that relate to waste water. Vietnam's CERs come from fugitive emission and hydropower projects. Although Vietnam only has one fugitive emission project, it is predicted to generate 37.8 per cent of total CERs of the country. The project is related to oil field flaring reduction. Meanwhile, the hydropower projects are related to the building of new dams and the utilization of rivers.

CERs from The Philippines are mostly from landfill gas projects. The other three countries, Cambodia, Singapore and Lao PDR are predicted to create only small amounts of CERs compared to other ASEAN countries. Cambodia will create its CERs mostly from biomass energy projects, as will Singapore. Lao PDR only has one registered project which is related to energy efficiency in the food industry.

\section{CERs as a Subsidy for Energy Efficient Investments}

There are currently 2,344 registered CDM projects around the world which are expected to generate 1.85 billion CERs by 2012. The total transaction value of the CERs is highly dependent on the carbon price created in emission markets. The price of CERs in the Europe Climate Exchange (ECX) fluctuates with the highest price so far in May 2010 at $€ 14.55$. On average, the price level in 2010 was $€ 12.59$. Given the same price level, the total value of CERs in 2012 is expected to be more than $€ 23$ billion. About 86.5 per cent of total CDM investments are located in the Asia-Pacific region with a total value of more than US\$63 billion. 


\subsection{The Potential of CDM Projects in Brunei}

\subsubsection{The Potential of Hydropower}

The Brunei Darussalam Long-Term Development Plan (Prime Minister Office \& Brunei Darussalam, 2007) has stressed the government's intention to provide adequate electricity supply to meet increasing demand in the future. Several studies have identified the hydropower potential of the Temburong River in Brunei (for example, Asia Pacific Energy Research Center (APERC), 2010). The hydropower potential capacity from the river is approximately $80 \mathrm{MW}$ with potential production of $300 \mathrm{GWh}$ per year (APERC, 2010). To be considered as a small-scale hydro power plant for CDM project, the maximum output capacity should be equal to $15 \mathrm{MW}$. The CERs generated by the project can be traded through global emission trading. Brunei can thus gain not only electrical output from the project, but also revenue from emission trading. Any risk of negative environmental impact from a small-scale hydro power plant development related to the proximity of Ulu Temburong National Park must be carefully evaluated.

\subsubsection{The Potential of Solar Photovoltaic}

Another potential renewable energy resource in Brunei is solar energy. The Tenaga Suria Brunei (TSB), which is a cooperation project between Brunei and Mitsubishi Corporation, Japan is located at the Seria Power Station in the Belait district with capacity of 1.2 MW (APERC, 2010). The project is estimated to result in emission reductions of $940 \mathrm{tCO}_{2} \mathrm{e}$ per year. Based on the TSB experience, this project will not only become a demonstration project for the utilization of solar energy in the future, but it could also be an important milestone for Brunei to enter the global carbon market.

Table 3. Share of CDM's projects investment 2010

\begin{tabular}{cccc}
\hline Host country & $\begin{array}{c}\text { Registered } \\
\text { Projects }\end{array}$ & Million US\$ & $\begin{array}{c}\text { Share of } \\
\text { Investments }\end{array}$ \\
\hline Asia-Pacific & 1770 & 63050.7 & $86.5 \%$ \\
China & 929 & 48134.4 & $66.0 \%$ \\
India & 526 & 11272.1 & $15.5 \%$ \\
ASEAN & 245 & 2016.9 & $2.7 \%$ \\
Rest of Asia & 70 & 1627.3 & $2.3 \%$ \\
Latin America & 478 & 7185.3 & $9.9 \%$ \\
Africa & 44 & 1563.4 & $2.1 \%$ \\
Middle-East & 26 & 843.4 & $1.2 \%$ \\
Europe and Central Asia & 26 & 260.4 & $0.4 \%$ \\
Total & 2344 & 72903.2 & $100 \%$ \\
\hline
\end{tabular}

Data Source: UNEP Risø Centre, 2010.

Table 4. Potential solar radiation in ASEAN countries

\begin{tabular}{ll}
\hline Country & $\begin{array}{l}\text { Potential Solar Radiation } \\
\left(\mathrm{kWh} / \mathrm{m}^{2} / \text { day }\right)\end{array}$ \\
\hline Brunei Darussalam* & 5.3 \\
Cambodia & 5 \\
Indonesia & 4.8 \\
Lao PDR & $4.5-4.7$ \\
Malaysia & 4.5 \\
Philippines & 5.1 \\
Thailand & 5.1 \\
Vietnam & 5 \\
\hline
\end{tabular}

Data Source: Lidula, Mithulananthan, Ongsakul, Widjaya, \& Henson, (2007).

Note: * Data for Brunei Darussalam extracted from NASA. Surface Meteorology and Solar Energy, 2010. 
The TSB experience demonstrates that there are opportunities to develop small-scale solar PV power plants that can be combined with the existing fossil-fuel based power stations. Brunei has high potential for solar energy utilization since it has high values of solar radiation with a small range of variation. Table 4 shows that Brunei has the highest potential of solar radiation in the ASEAN region.

\subsubsection{The Potential of the REDD+ Mechanism}

Currently, the REDD + mechanism is evolving towards its incorporation into the post-2012 climate regime after the first Kyoto Protocol commitment period ends (Sasaki \& Putz, 2009; Adhikari, 2009). The current carbon market excludes the REDD+ mechanism and only allows trading of CERs from afforestation and reforestation under CDM projects (Corbera \& Schroeder, 2011). However, the REDD+ mechanism is expected to be in compliance with the future carbon market.

The REDD + mechanism seems particularly important for Indonesia, since a large part of greenhouse gas emissions in Indonesia comes from forest degradation and land conversion. Several issues need consideration. First, the country should commit to the implementation of its national spatial plan and to the achievement of its national target for the forestry sector. Secondly, in relation to sustainable forest management, the activities of forest conservation should provide benefits to local societies. In order to implement the sustainable forest management concept, the Indonesian government, in cooperation with some international institutions, has recently been working on pilot projects of sustainable forest management in several locations in Indonesia. Thirdly, inconsistent policies across different sectors, such as forestry, agriculture and mining, and the decentralized governance system in Indonesia increase the possibility of disjointed and contradictory policies between central and district governments. Therefore, it is very important for Indonesia to re-assess all relevant policies related to forest management at national and district levels.

The REDD + mechanism has three implementation phases (Meridian Institute, 2009). Phase 1 focuses on national REDD+ strategy development and capacity building towards REDD+ readiness. Activities in this phase, including institutional strengthening, strategy development and demonstration activities, are supported by voluntary contributors such as UN-REDD, the World Bank and other bilateral arrangements. Phase 2 is related to the implementation of national REDD + policies and measures. These activities should be supported by international financial instruments with clear commitments. Activities included in Phase 1 would be incorporated into the Phase 2 instruments, when the financial instruments for Phase 2 have been established.

Phase 3 is a full-scale implementation of the REDD+ mechanism. Payments would be delivered to respective countries based on their performance in forest emission reduction and removal against the reference levels. The compensation mechanism should be supported by a compliance grade in measuring, reporting and verification (MRV) of emission reduction and removal from the forestry sector. At this phase, the participating countries could sell their carbon units from the REDD + mechanism in international carbon markets.

As for the three phases of REDD+ implementation, Brunei has a relatively unique position. We refer to the four elements influencing each phase of the REDD+ mechanism as described by Angelsen, Brockhaus, Sills, Sunderlin and Wertz-Kanounnikoff (2009), namely crediting scale, performance indicators, funding and MRV system. Regarding the crediting scale of carbon, Brunei has an opportunity to be in Phase 3, in which the REDD+ mechanism is in full-scale implementation. This is because authorization to control and manage forest areas in this country is at the national level allowing a national level crediting scale.

On the other hand, two elements, i.e. crediting scale and MRV system, indicate that Brunei is still in the early phases of REDD+. Firstly, Brunei is currently working on a national greenhouse gas inventory project and cannot yet quantify the changes of forest carbon quantity nor the reference level, which are performance indicator elements in Phase 3. Secondly, Brunei is unable to generate a sophisticated MRV system due to a lack of measurement data. Brunei's advantage lies in its well-managed forest area and a strong commitment to preserve the forest. Therefore, Brunei could focus on developing the performance indicators and the MRV systems. When the post-2012 climate regime begins, Brunei would be well-prepared to gain benefits from the next climate regime.

\subsection{CDM Projects and Investment Costs}

This section discusses some registered Solar Photovoltaic (PV) power plants as CDM projects, which are potential CDM projects for Brunei. These projects are mainly located in South Korea, with one in the United Arab Emirates (UAE) and are mostly small-scale with capacities less than $15 \mathrm{MW}$.

Investment costs for a Solar PV power plant are much higher than for conventional types of power plant, such as coal-fired, natural gas-fired and even wind energy power plants. The average CDM Solar PV power plant required 
US $\$ 6,674 / \mathrm{kW}$ in investment costs. The IEA gives a range for investment costs of solar photovoltaic of between US\$2,775 and US\$10,164 per kW (International Energy Agency (IEA), 2005) as shown in Figure 1.

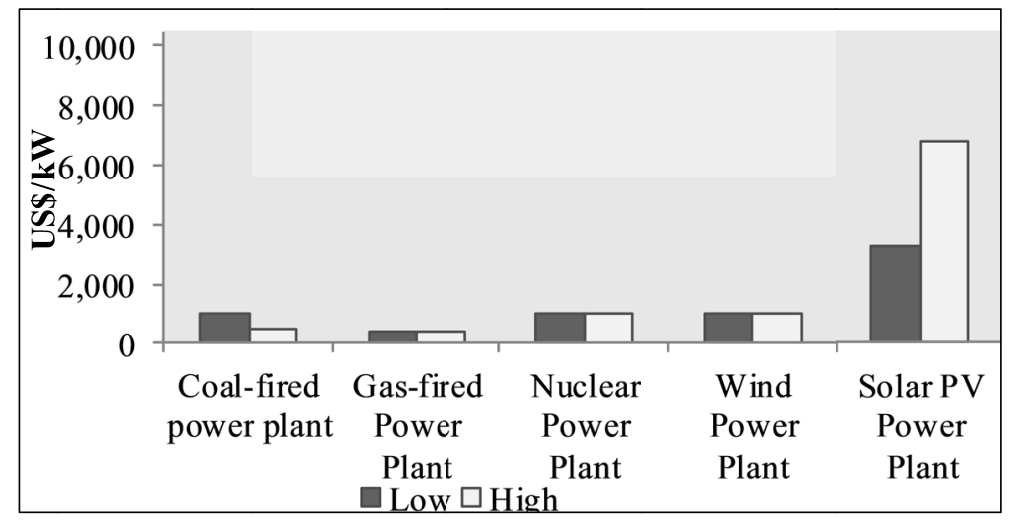

Figure 1. Investment cost per kW by type of power plant

Data Source: IEA, 2005.

It is interesting to consider investment costs necessary to reduce $\mathrm{CO} 2$ for selected Solar PV-CDM projects based on reviews and calculations of some registered CDM project's Project Design Documents (PDDs). The projects have either a 7-year or a 10-year crediting period of CERs. Calculations have been made based on the investment costs and $\mathrm{CO}_{2}$ reduction during the crediting periods. They show that the average ratio between investment costs of Solar PV-CDM Projects and total $\mathrm{CO}_{2}$ reduction is US $\$ 889 / \mathrm{tCO}_{2}$. However, the data indicate that for some natural gas-fired power plant CDM project's PDDs, the ratio of investment cost $/ \mathrm{tCO}_{2}$ reduction is less than US $\$ 100 / \mathrm{tCO}_{2}$. As an illustration, in Batam, Indonesia, there is a registered Gas-Fired Power Plant CDM project with capacity of 11.4 MW and a reduction target of $12,798 \mathrm{tCO}_{2}$ per year. The reduction of $\mathrm{CO}_{2}$ will be obtained from the use of efficient engines fuelled by natural gas. The project will install and operate six new sets of gas engines and the generated electricity will be transmitted to the Batam grid. The ratio of investment $\cos t / \mathrm{tCO}_{2}$ reduction of the project is US\$78.1/tCO $\mathrm{CO}_{2}$ for a 7 -year crediting period.

Regarding wind energy CDM projects, our calculations (based on wind power CDM projects with capacity less than $100 \mathrm{MW}$ ), show an investment cost/tCO $\mathrm{CO}_{2}$ reduction ratio of US\$109/tCO $\mathrm{tC}_{2}$ on average for a 7 -year crediting period. The average investment cost per $\mathrm{kW}$ is US $\$ 1,412 / \mathrm{kW}$. The hydro power CDM projects show a lower ratio of investment $\operatorname{cost} / \mathrm{tCO}_{2}$ reduction than the wind power-CDM project at US\$68/tCO $\mathrm{CO}_{2}$ overage.

Table 5 shows that Solar PV has the highest level of investment cost $/ \mathrm{tCO}_{2}$ reduction ratio. It is interesting to compare the market price of CERs in the ECX and the ratio of investment cost $/ \mathrm{tCO}_{2}$ reduction for different projects. Since the total reduction of $\mathrm{CO}_{2}$ represents the fixed amount of CERs to be produced during the crediting period, the investment required to produce one $\mathrm{tCO}_{2}$ reduction can be considered to be the production cost of one unit of CER, ignoring operation and maintenance costs over the crediting period and the time value of money.

Table 5. Ratio of investment costs to $\mathrm{CO}_{2}$ reduction in electricity generation

\begin{tabular}{|c|c|c|c|c|}
\hline Ratio & Solar PV & Wind Power & Hydro Power & Natural Gas \\
\hline $\begin{array}{l}\text { Investment to } \mathrm{CO}_{2} \\
\text { Reduction }\end{array}$ & $\mathrm{US} \$ 889 \mathrm{tCO}_{2}$ & $\mathrm{US} \$ 109 \mathrm{tCO}_{2}$ & $\mathrm{US} \$ 68 / \mathrm{tCO}_{2}$ & $\mathrm{US} \$ 43 / \mathrm{tCO}_{2}$ \\
\hline $\begin{array}{l}\text { Investment to } \\
\text { Electricity Generation }\end{array}$ & US\$6849/KW & US\$1412/KW & US $\$ 1328 / \mathrm{KW}$ & US\$493/KW \\
\hline
\end{tabular}

Data Source: UNEP Risø Centre's data, 2010.

Assuming a price of US\$17.12/tCO $\mathrm{CO}_{2}$ reduction for all types of power plants, especially Solar PV-CDM projects. Thus, revenue from CERs will not fully fund the investment in $\mathrm{CO}_{2}$ reduction. In this case, the projects are still strongly dependent on sales of 
electrical services as the main source of revenue. However, revenue from CERs' sales can contribute positively to projects through their contribution to total revenue and thereby improve the economic feasibility of the projects.

Based on a review of some PDDs of registered CDM projects, the authors have estimated that revenue from the sale of CERs may increase total revenue by approximately 12.3 per cent. In terms of economic feasibility, sales of CERs may increase the Internal Rate of Return (IRR) by more than 2 per cent compared to the IRR without the sale of CERs.

\subsection{Feasibility of CER Sales in Brunei}

Although Brunei's conservation record for forests is exemplary, it is somewhat more profligate in the energy sector. Electricity is subsidised by the generators paying a highly-subsidized price for natural gas to the producer, Brunei Shell Petroleum (BSP). Not only is the price of natural gas as fuel for electricity fixed, residential and commercial tariffs are also highly subsidized despite a recent change to an increasing block price from a declining block pricing scheme. Retail petrol prices in Brunei have been estimated to be approximately half the commercial price and have no sales or other taxes imposed (Lawrey \& Pillarisetti, 2011).

The impact of energy subsidies in Brunei can be seen in the way society consumes energy: per capita use of electricity is double the world average and 80 per cent of the 32 high-income countries (Lawrey \& Pillarisetti, 2011). Generating efficiency by the government generator is also relatively low.

Public transport is viewed as an inferior good in Brunei, used mainly by low income families who cannot afford to own a car. Car ownership is one of the highest in the world. Lawrey and Pillarisetti (2011) have argued that, while acknowledging the inefficiencies associated with energy subsidies, their removal does not have clear cut, unequivocal, theoretical support to improve economic welfare once other distortions are taken into account. In this regard, CDM projects designed to improve energy efficiency could result in a win-win situation in that the revenue from the sale of CERs could be used to partly offset the investment costs required and/or ease the transition for the consumer of a gradual removal of subsidies. Investment in CDM projects can be initiated by the two government agencies supplying electricity which can further ensure that the projects are aligned with national development plans.

\subsection{Some Potential Barrier Issues Related to the Implementation of CDM Projects in Brunei}

Though Brunei has a low volume of CDM opportunities at present (Table 6), low political risk gives it an advantage to be a host country for CDM projects (similar to Singapore). Countries with high potential for CDM initiatives in the ASEAN region are Thailand, Philippines, Malaysia, Indonesia and Vietnam. Indonesia and Vietnam have a disadvantage regarding political risk. Cambodia, Lao PDR and Myanmar are considered as countries with a low volume of CDM opportunities and high political risk.

Table 6. CDM volume - political risk matrix for ASEAN countries

\begin{tabular}{ccc}
\hline & Low Political Risk & High Political Risk \\
\hline Low Volume of & Singapore & Cambodia \\
Executable CDM & Brunei Darussalam & Lao PDR \\
Opportunities & Thailand & Myanmar \\
& & Indonesia \\
High Volume of & Philippines & Vietnam \\
Executable CDM & Malaysia & \\
Opportunities & .
\end{tabular}

Source: Adapted from capacity for Sustainable Development Energy \& Climate Consultants (2005).

Technological issues may become a potential barrier for CDM project implementation. In some cases, the latest technology is not always available in the host countries of CDM projects which therefore require technology transfer from overseas. But technology transfer from developed country to developing country has consequences, such as Intellectual Property Rights (IPRs) issues (World Bank, 2008). Brunei should promote intellectual property rights protection through the implementation of its IPRs law. Currently, Brunei is ranked third for intellectual property rights protection among ASEAN countries, after Singapore and Malaysia (Schwab, 2009). Brunei's small land area and population can only allow small-scale CDM projects. These will tend to generate a small number of CERs to be traded in carbon market and thus affect the feasibility of CDM project implementation 
in Brunei. In addition, Brunei is relatively new to the Kyoto Protocol and is still in the process of establishing infrastructures related to the Protocol (Officer of Ministry of Development, personal communication, May 2010). To be a host for CDM projects, Brunei should establish a Designated National Authority (DNA). The DNA has responsibility to verify whether the proposed project will contribute to achieving the country's sustainable development goal. The DNA of a host country should have quick and transparent procedures for screening, evaluation and approving projects in order to attract CDM investments (Lee, 2004). Since Brunei is in the process of developing its infrastructure (Lawrey, 2010), any PDD of CDM projects cannot be verified at this moment.

\section{Conclusions}

The newly emerging carbon market is allowing several countries in ASEAN to benefit from reduction of carbon emissions, or increasing absorption of carbon, through the CDM and potentially, REDD+. Brunei at present is not participating the carbon trade, although it is a signatory to the Kyoto Protocol. This paper has identified the potential for the sale of CERs to offset at least some of the increased capital costs associated with renewable energy investments in ASEAN. For Brunei, implementation of energy efficiency and conservation measures seems to have more potential benefits than forest conservation. This highlights one of the ethical criticisms of the carbon market and the CDM, namely that it rewards a change in polluting and destructive behaviour but does not reward a history of good behaviour.

There are many challenges for Brunei to participate in emission trading. The country would have to create institutions and procedures in order to be able to implement CDM projects and create CERs. There certainly is potential for CDM opportunities in the energy sector and that current moves to increase energy efficiency and invest in renewable energy technologies could be undertaken in conjunction with the creation of CERs in anticipation of the post-2012 climate regime.

\section{References}

Adhikari, B. (2009). Reduced emissions from deforestation and degradation: Some issues and considerations. Journal of Forest and Livelihood, 8(1), 14-24.

Angelsen, A., Brockhaus, M., Sills, E., Sunderlin, W. D., \& Wertz-Kanounnikoff, S. (2009). Realising REDD+: National strategy and policy options. Bogor, Indonesia: CIFOR.

Asia Pacific Energy Research Center (APERC). (2010). APEC Energy Overview 2009. Singapore: APEC Secretariat.

Benwell, R. (2009). Voluntary aspects of carbon emissions trading. International Journal of Environmental Studies, 66(5), 605-618. http://dx.doi.org/10.1080/00207230903303794

Capacity for Sustainable Development (CAP SD) Energy \& Climate Consultants. (2005). Improving the competitiveness of Southeast Asia on the global CDM market. Discussion paper, CDM ASEAN.

Capoor, K., \& Ambrosi, P. (2009). State and trends of the Carbon Market 2009. Washington D.C: World Bank.

Common, M., \& Stagl, S. (2005). Ecological economics: An introduction. Cambridge, UK: Cambridge University Press. http://dx.doi.org/10.1017/CBO9780511805547

Corbera, E., \& Schroeder, H. (2011). Governing and implementing REDD+. Environmental Science and Policy, 12(2), 89-100. http://dx.doi.org/10.1016/j.envsci.2010.11.002

Haites, E. (2008). Negotiations on additional investment and financial flows to address climate change in developing countries. In The Bali road map: Key issues under negotiation. New York: UNDP.

Helm, D. (2005). Economic instruments and environmental policy. Economic and Social Review, 36(3), 1-24.

International Energy Agency (IEA). (2005). Projected costs of generating electricity - 2005 update. Paris, France: $\mathrm{OECD} / \mathrm{IEA}$.

Lawrey, R. (2010). An economist's perspective on economic diversification in Brunei Darussalam. CSPS Strategy and Policy Studies Journal, 1, 13-28. Brunei Darussalam: Centre for Strategic and Policy Studies.

Lawrey, R., \& Pillarisetti, J. R. (2011). Energy subsidies versus economic efficiency: practical and theoretical issues in the case of Brunei Darussalam. Asian Social Science, 7(3), 108-116.

Lee, M. K. (2004). CDM Information and Guidebook (2nd ed.). Denmark: UNEP Risoe Center and UNEP.

Lidula, N. W. A., Mithulananthan, N., Ongsakul, W., Widjaya, C., \& Henson, R. (2007). ASEAN towards clean and sustainable energy: Potentials, utilization and barriers. Renewable Energy, 32, 1441-1452. http://dx.doi.org/10.1016/j.renene.2006.07.007 
Meridian Institute. (2009). Reducing Emissions from Deforestation and Forest Degradation (REDD): An options assessment report. Retrieved from http://www.REDD-OAR.org

Murphy, D., Drexhage, J., \& Wooders, P. (2009). International carbon market mechanisms in a post-2012 climate change agreement. Manitoba, Canada: International Institute for Sustainable Development.

Prime Minister's Office, Brunei Darussalam. (2007). Brunei Darussalam Long Term Development Plan. Brunei Darussalam: Department of Economic Planning and Development.

Sasaki, N., \& Putz, F. E. (2009). Critical need for new definitions of "forest" and "forest degradation" in global $\begin{array}{llll}\text { climate change agreements. Conservation } & \text { 226-232. }\end{array}$ http://dx.doi.org/10.1111/j.1755-263X.2009.00067.x

Schwab, K. (2009). The Global Competitiveness Report 2009 - 2010. Geneva, Switzerland: World Economic Forum.

United Nations Framework Convention on Climate Change (UNFCCC). (2008). Kyoto Protocol reference manual on accounting of emissions and assigned amount. Bonn, Germany: Climate Change Secretariat, UNFCC.

World Bank. (2008). International Trade and Climate Change: Economic, Legal and institutional Perspectives. Washington DC: World Bank.

\section{Notes}

Note 1. In the carbon market, the following terms relate to units of measurement for trade. Assigned Amount Units (AAUs) are levels of allowed emissions over the commitment period 2008 - 2010. Removal Units (RMU) relate to land use, land use change and forestry (LULUCF) activities, such as reforestation. An Emission Reduction Unit (ERU) is generated by a Joint Implementation project. A Certified Emission Reduction (CER) is generated by a Clean Development Mechanism project activity. All the units are in tons of CO2e (UNFCCC, 2008). 